\title{
Obstacles in Women Education: A Study of Societal Structure of Pakhtun Society
}

\author{
Muhammad ljaz Khan \\ Department of Sociology, University of Sargodha, Sargodha, Pakistan \\ Nabeela Malik \\ Department of Sociology, University of Sargodha, Sargodha, Pakistan \\ Nighat Nazir \\ Department of Law, International Islamic University, Islamabad, Pakistan \\ Shahzad Khaver Mushtaq \\ Department of Sociology, University of Sargodha, Sargodha, Pakistan \\ Sohail Mujahid \\ Department of Sociology, University of Sargodha, Sargodha, Pakistan
}

Doi:10.5901/mjss.2014.v5n23p2116

\begin{abstract}
The women status and their role in society are very important for the progress of developing countries. As women constitute almost half of the human resources. The role of women in development is closely related to the socio- economic progress which can be achieved through education. Moreover, women can perform the best part for the development of contemporary society. But the status of women in Pakistan especially Pakhtun society is different as compare to western countries. Women are often considered to be a weaker and vulnerable group in society in term of education, employment and business opportunities, legislation and decision making. Gender discrimination may have an adverse impact on a number of valuable development goals. As gender inequality in education and access to resources may prevent a reduction in child mortality, fertility, and an expansion of education for the next generationwhile in the past decades much attention had been paid towards women problems in all over the world. The right of education has become an important and hot burning issue international level and socio-political on domestic level as well.
\end{abstract}

Keyword: Obstacles, Women Education, Social Structure of Pakhtun Society.

\section{Introduction}

Education is basic right of every individual, which is recognized by Universal Declaration of Human Rights 1948, and by others Human rights conventions. The right to get free education without any discrimination has been recognized most of the international human rights documents. It's a state responsibility to provide the education and basic necessity of life. As women education directly leads to the better reproductive health, improved family health, and empowerment and economic growth while educated women can perform healthy role for the management of household matters. In Pakistan, almost the half population constitutes on female, but this major part of population is discriminated from the basic right of education. If half of the population of any nation is illiterate and can't access on their basic right then how could be a nation developed. Such as male are considered the most dominated part of society. In this scenario, education is the key to breaking vicious circle of ignorance, exploitation and empowering women and girls to improve their lives.it is the integral part for the development of human society. The status of women in respect of education is very complicated at the primary, middle, secondary and higher level. There is gender inequality and discrimination are the key factors which severely effecting the primary educational enrolment of girls as compare to boys. The situation of female education is more serious in the rural areas of Khyber Pakhtunkhwa especially in Malakand division, where women are limited to only four walls of house. Due to the rigid customs and traditions female education ratio is very low. This research study 
highlighted the Pakhtun culture and its impact on women education. Nevertheless as a problem, women require special kind of attention and encouragement especially in the educational sectors, because developments without the participation of women will remains incomplete which will be achieved through education.

\section{Literature Review}

Education is an important component for the development of a society. It is not only a source of getting knowledge and to improve skills but also to improve the awareness among both sexes.Many scholars and organizations have worked on this issue on their own perspective, but still need for reformation.

It is well known fact that educated woman can well determine the family education Roberts (1978). Immense benefits of education correlate with social, economic and environmental quality. Barriers to girls' education can take different forms across nations/societies, depending upon the socio-economic, religious and cultural context. Furthermore, barrier can be perceived as either intrinsic or extrinsic to girls in relation to how they experienced educational participation. As will, some barriers can be obvious while other is subtle and tacit. Some of the major socio-economic constraints include poverty, week legal framework around education, issue of safety and security around school affecting girls, lack of relevance of school to the lives of children, unemployment, underemployment, over population, no proper utilization of resources etc also decrease women's education in the country. Majority of the Asian Countries are poor, and in the absence of welfare state it is svery difficult for the family to afford both the education of boys and girls (RobinsonPant, 2004:473).

According to the parents view educating sons as investment because the sons will be responsible for caring of aged parents. On the other hand, parents may consider that the education of daughter's is wastage of money because daughters will eventually live with their husbands' families and the parents will not benefit directly from their education. Also, daughters with higher levels of education will likely have higher dowry expenses as they will want a comparably educated husband. However, education sometimes lowers the dowry for a girl because it is viewed as an asset by the husband's family (Dreze and Sen, 1995). However educating girls is a very beneficial both for the family as well as for the country as will in order to achieved sound development of family, community and society at large (Stromquist, 1995:454).

The benefits of educating females, although not as thoroughly examined, are of no less importance, besides the typical market benefits, educating females can also yield other positive externalities such as enhancing the gains that result from educating males (Hill and King, 1991). Throughout the history education remains a man asset. The previous research shows that during the eighteenth century and into the nineteenth century, teachers were considered pillars of their communities, at that time, teaching was almost totally an all-male profession. As women began entering the teaching profession in greater numbers, they were restricted primarily to teaching the early grades, where the goal was not so much to educate children as to civilize them. As the year went by, women taught more than men. However, the position of principal a position of greater status than that of teacher in most grade schools remained male- populated (Strober\& Tyack, 1980:493; Tyack, 1976: 263). During this century, the teaching profession became more dominated by women, especially among the primary grades. However, women teachers found their career paths blocked at higher levels of the educational system (Szafran\& Austin, 1984).

Poverty and illiteracy are correlated with each other. Illiteracy among poor and rural people is common. The most marginalized group deprived of education is the rural girls from poor and illiterate families. Parents' education has a strong influence on children's education, especially of girls'. Children of those parents that have obtained some schooling are much more likely to have attended school as compared to those whose parents have themselves never been to school. This difference is much more pronounced in rural areas compared to urban, and for girls relative to boys. Lack of parent teacher communication in case of poor illiterate families, is a major factor for lower learning achievements as identified by head teachers and teachers (UNESCO, 2001:30).

\section{Objectives of the Research}

The main objectives of research are to explore the socio- cultural factors which effecting women's level of education in socio-cultural structure of Khyber Pakhtunkhwa.

1. To identify the socio-Cultural obstacles regarding female education in Khyber Pakhtunkhwa.

2. To know about people response towards female education in KPK.

3. To suggestpossible remedies to minimize constrains regarding women education.

Furthermore researcher will observe and collect quality secondary data regarding women's education from different archives regarding the subject. 


\section{Result and Discussion}

As discussed earlier that in Paukhtun society women are consider to live only in four walls of home. In order to assess to the right of women education and the societal structure of Khyber Pakhtunkhwa 200 samples were taken from the selected area. As the issue is related to women education so the respondents were female. Open ended question were asked from the respondents, which based on what are main causes of female illiteracy.

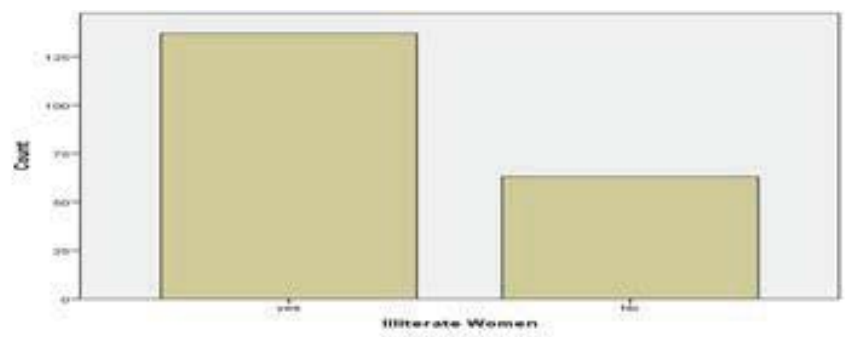

Above graph shows the literacy ratio of the female of targeted area. Majority of the respondents i.e. $68.5 \%$ are of the view that female are illiterate and the remaining respondents of the view that female are literate but not allowed to attain the formal school or high school. In Pakhtun society, right of woman education is considered as less important in society as compared to male education. Females are considered inferior part of society, therefore they are only allowed to go to madrasa, and their right of higher education is considered against their custom and tradition.

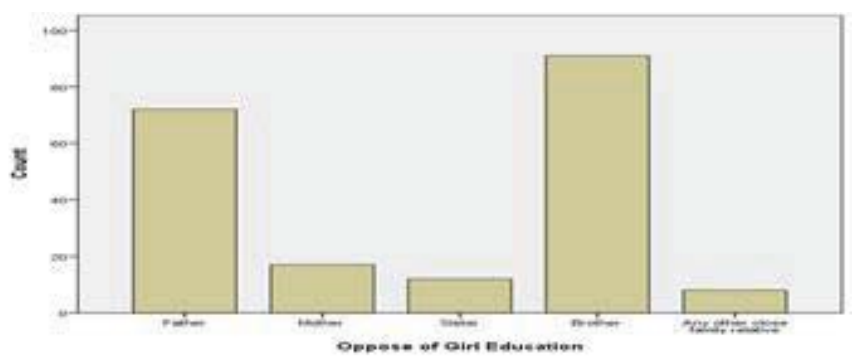

Above graph shows the opposing authority of the female from the basic right of education at home. Majority of the respondents i.e. (45\%) are of the view that female are restricted in the four walls of the home and don't permitted to get formal education or higher education. $36 \%$ of the respondent of the view that females are not allowed to get formal education by their family, $8.5 \%$ respondents are of the view that a mother is a most important member of a family and have a great influence on family matters and development.6\% of the respondent indicate that, women are usually considered main opposing authority in the family. Beside this fact, other conservative social factors are also involved in their education system which restrict from their basic right of education.

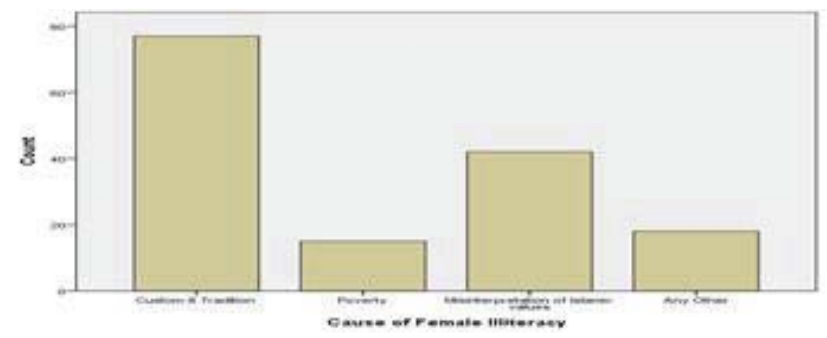

Responses of the respondents in above graph shows that majority of females were deprived from their basic right of education i.e. $50 \%$ respondent were of the view that females were illiterate in their family because of societal custom and traditions. $27.6 \%$ of respondent of the view that females are deprived from their basic right of education because of misinterpretation of Islamic values presented by the religious leaders, while $11.8 \%$ respondent of the view that most of the family are living under the poverty line, and marked the poverty as a main cause of women deprivation from their basic right of education. 


\section{Conclusion\&Recommendations}

It is concluded from the data analysis and subsequent discussion that, the problem of deprivation of women from Education is a serious threat towards their basic human rights. It is a complex problem which requires coordinating solutions, involving the participation of both the state and civil society. It is a well-known fact that education plays an important role in the development of a nation. Half of population of Pakistan consists of female and if they are deprived from the right of education, how can Pakistan stand among the prosperous and developed countries of the world? Regressive social practices, deep-rooted in tribal customs and traditions, attached with misinterpretation of religious knowledge and the also poverty because most of the people have low living standard, are the main cause of women deprivation of the basic right of education in the Pakhtun society. To change these social attitudes needs sustainable legal and social efforts.

This research paper find out that the problem of deprivation of women from their basic right of education is a big hurdle in the way of development and it needs some serious and sincere steps to remove this evil from the society. The following suggestions are recommended in this regard:

This research paper compromises recommendations for concerned groups for the improvement of situation of educational empowerment of women in Khyber Pakhtunkhwa (KPK) and on further investigation related issues to the basic right of women education as suggested by the results of the study. This study was related only to an expert perspective about educational empowerment of women in Khyber Pakhtunkhwa(KPK); it is recommended that the perceptions of the beneficiaries could also be helpful in this area for further research. As Religious, Political and community leader play an important role to provide the basic right of education to women in society. They should come forward with real efforts to meet the challenges of women education in Pakhtun society. The religious leaders should propagate the religious values and ideas which are based upon the true teachings of Islam and applied in true letters and spirit. The role of media cannot be ignored to remove of existing standards and values and the contribution they could make to raising the public's awareness and promoting changes in human relationships, the media should address the phenomenon of the right of women education with the aim of acting as mechanisms of identification and education, by informing people about the magnitude of the problem, the forms it can take and the rights protecting women. In order for the media to play a positive role in preventing of women education, Governments must promote communications policies which make it possible to denounce acts against the female education to coordinate public awareness campaigns that portray any act of aggression against women education as a violation of human rights as unacceptable and as a crime.

The above recommendations presented in this research paper are not comprehensive. This is, above all, because achieving the goals of providing the basic right of education to women in the countries will require, at all levels and in all spheres where the problem is manifested, the political will of Governments and the obligation on the part of the entire population; these are essential if we are to create a more just and impartial society and achieve true development within a framework of peace.

\section{Bibliography}

Dreze, J. and Sen, A. (1995). INDIA Economic Development and Social Opportunity, New Delhi: Oxford University Press. Education Department Survey (EDS). (2005).

ELSaadawi, nawal (1980), the Hidden Face of Eve: Women in the Arab World. Zed, London.

King, Elizabeth and Anne Hill. (1993). Women's Education in Developing Countries: Barriers, Benefits, and Policies. Baltimore: Johns Hopkins Press.

Mundy, K. "Global Governance, Educational Change; CompativeEducation 43, №. 3 (2007): 339-342.

Roberts, Bryan (1978), Cities of peasants: the Political Economy of Urbanization in the third World, Edward Arnold, London.

Robinson-Pant, A. "Education for woman: whose values count?" Gender and Education 16, No. 4 (2004):273-280.

Szafran, R., \&Austin, S. (1984). Universities and women faculty. New York: Pareger.

Strober, M., \& Tyack, D. (1980). Why do Women Teacher and Men Manage? A report on research on schools. Sings 5:494-503.

Stromquist, N. (1995). Romancing the Sate: Gender and Power in Education, Comparative education Review 39 (4), pp.423-454.

UNESCO/Aijaz. (2001) "Learning Achievements in Primary Schools of Pakistan, a Quest for Quality Education"; UNESCO/Govt. of Pakistan; Islamabad; p.30. 